\title{
The Approach to shanghai
}

\section{Walter N. Lacey}

To cite this article: Walter N. Lacey (1922) The Approach to shanghai, Journal of Geography, 21:7, 276-281, DOI: $10.1080 / 00221342208985000$

To link to this article: http://dx.doi.org/10.1080/00221342208985000

曲 Published online: 27 Feb 2008.

Submit your article to this journal $2 \pi$

Џ Article views: 3

Q View related articles $₫$ 


\title{
BIBLIOGRAPHY
}

1. Salisbury: Physiography, p. 132.

2. Dixon: A traffic history of the Mississippi River System (1909), pp. 37-60.

3. Tarr and Martin: College Physiography, pp. 108-109, 154, 155-159.

4. Brunhes: Human Geography, p. 212.

5. Corthell: The Mississippi Jetties.

6. Springer: What New Orleans is Doing. Illustraled Scientific American, Vol. 184, (Jan. 29, 1921) p. 14.

7. Salisbury, Barrows and Tower: Elements of Geography, pp. 120-211, 266, 338, $342-346,364-365,374-375,425-426$.

8. Frye and Atwood: Advanced Geography, pp. 19, 42, 296. Maps, 25, K5, 2-3,H4.

9. Huntington and Cushing: Principles of Human Geography, pp. 138, 139.

10. World Almanac (1921).

11. Current Periodicals.

12. Reports of National Waterways Commission, 1921. Washington, D. C. Government Printing Office.

\section{THE APPROACH TO SHANGHAI}

\author{
WALTER N. LACEY \\ Anglo-Chinese College, Foochow, China
}

Shanghai is China's chief port. Its location is such that it is the first place in China visited by the traveller, and for many a tourist it furnishes the sum total of his ideas of China.

As one approaches the coast of China on one of the trans-Pacific steamers his fellow passenger who has been there before will be heard to exclaim "land," and he will with difficulty agree that perhaps the experienced traveller is right; he had himself thought it a low-lying cloud on the horizon, or a dark streak of muddy water. The south bank of the Yangtze at this point is so low and flat that it is scarcely to be recognized on the horizon; the river is so wide that its north bank cannot be seen at all. Ultimately the south bank is seen as a level green plain and one thinks he sees a similar bank on his right, but it is only one of the islands that the silt has made and which furnishes excellent farm land for rice.

By this time the steamer begins to turn to the left and the passenger realizes he is in the midst of an anchorage: ocean liners and warships ride at anchor, noisy dredges and a stone breakwater testify to man's attempt to keep a good harbor. This is the mouth of the Whangpoo River, and the steamer (we are assuming it is one which can go up to Shanghai) is leaving the broad and yellow Yangtze. On the right a thriving little town is to be seen-a town such as one would expect at an outer anchorage, with its forts and military plants, its custom 
house and commercial warehouses, its "hotels" and small supply stores, and the terminus of the first railway built in China.

As the steamer moves slowly up the river the passenger is struck with the simple beauty of the low-lying level green river banks.

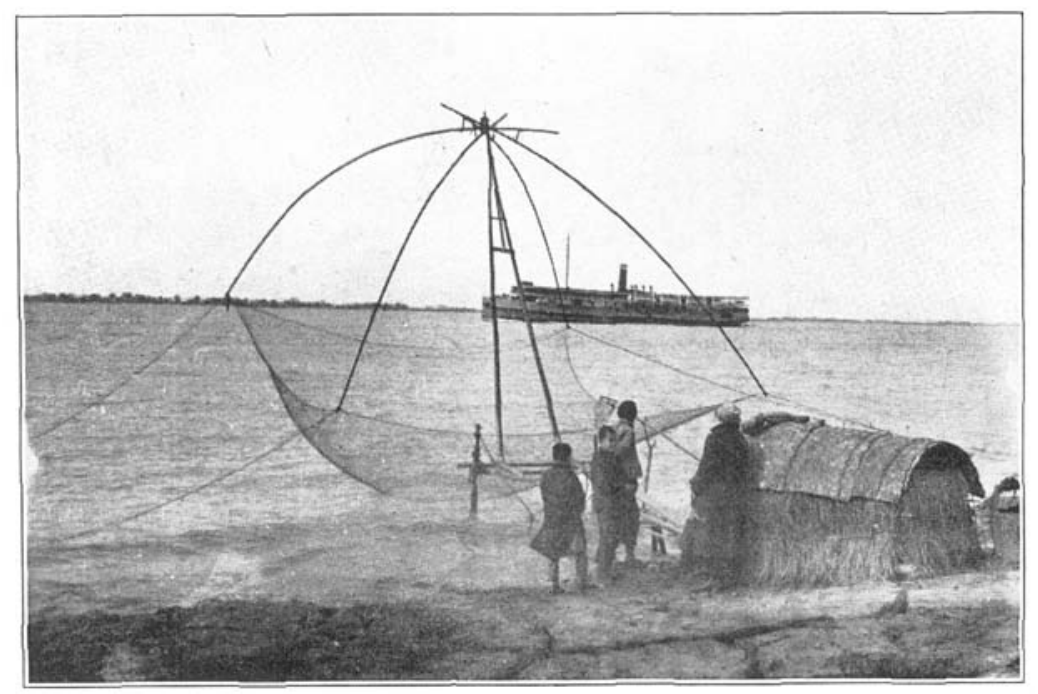

Fig. 1. Fishing on the banks of the Whangpoo

Here and there a fisherman has a net suspended at its four corners from a bamboo frame-work which forms one arm of a bent lever, and at intervals he steps on the weight of the other arm and lifts his net from the water, removing his catch from the net with a long bamboo dipper (Fig. 1). Here and there, dotting the river surface, are numerous

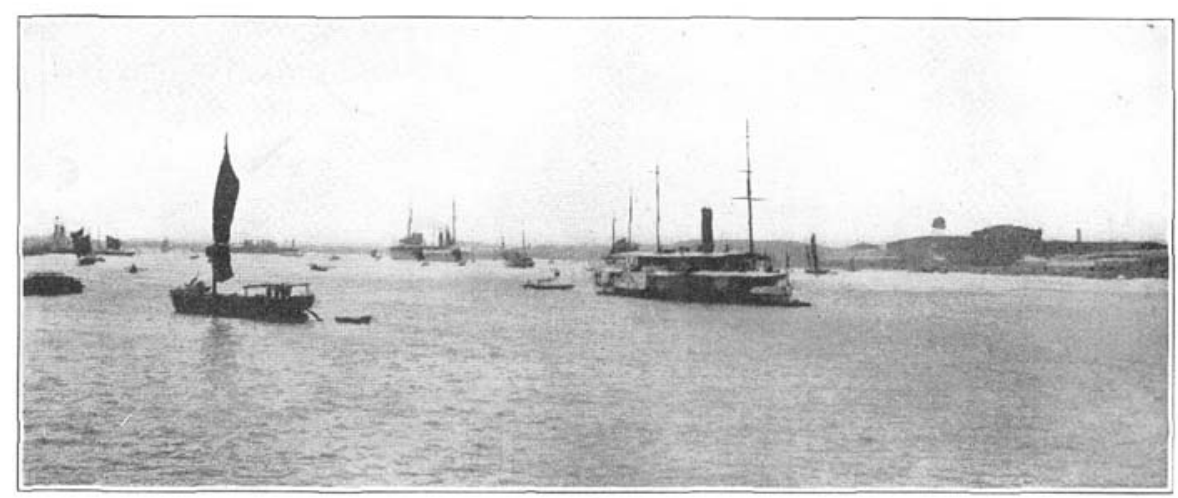

FIG. 2. In the Whangpoo River 
small boats, intended for two or three passengers, and propelled by a man in the stern pulling with the fish-like stroke of the oar, a method which seems to develop surprising speed.

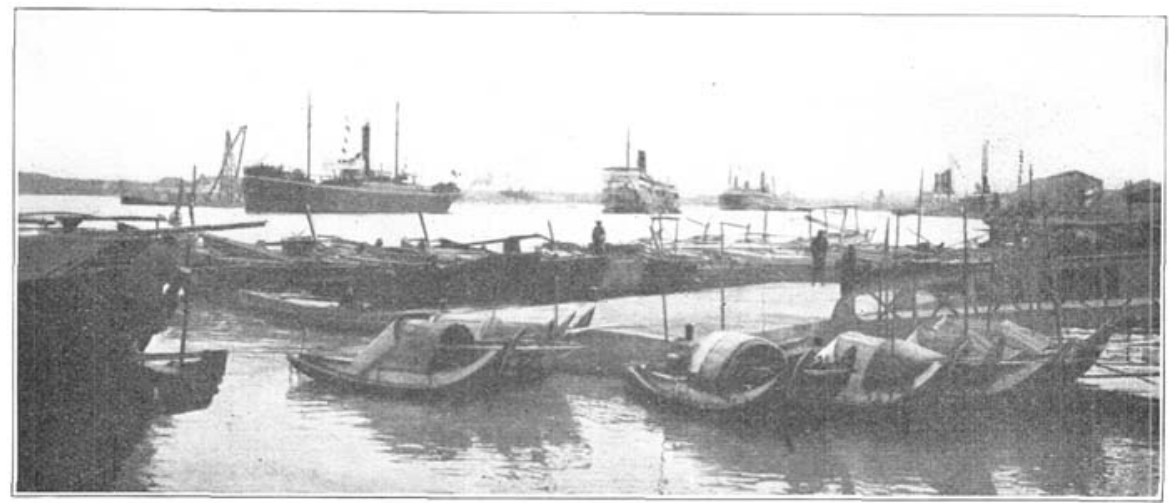

FIG. 3. In Shanghai harbor. Vessels at anchor in midstream

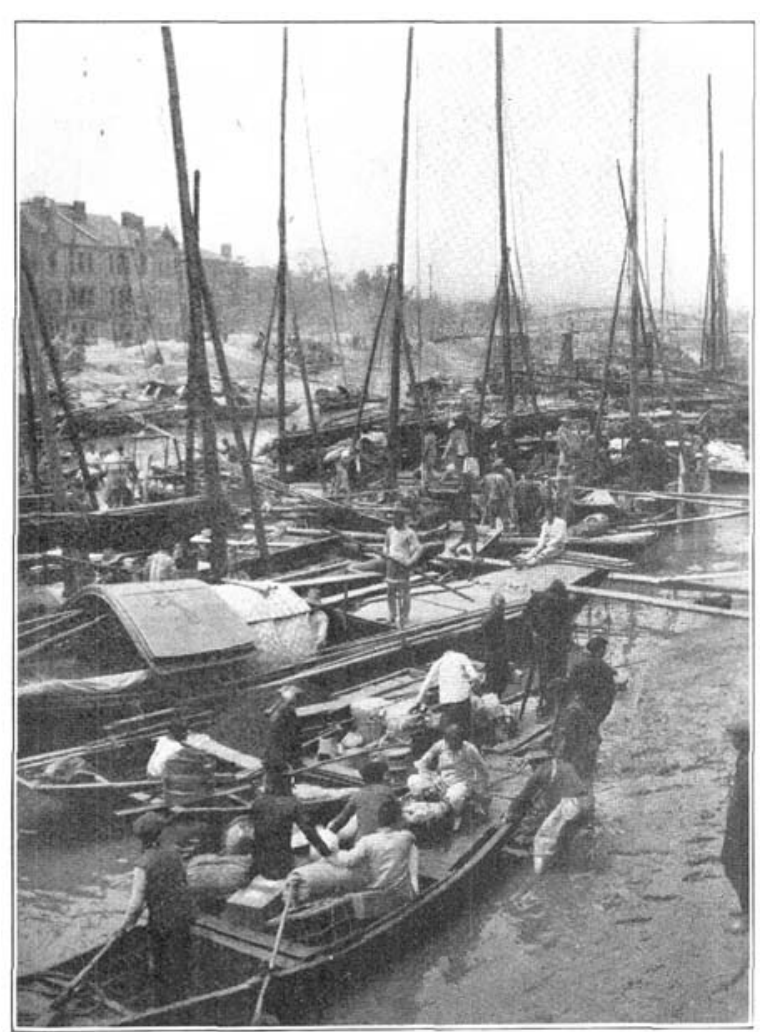

FIg. 4. Numerous small crafts at Shanghai

But these little boats are not the only craft in the river. Here the steamer passes a flotilla of the ancient style Chinese junks-those ungraceful ships with three big sails and eyes on either side of the prow-all of which makes a graceful picture as the flotilla floats Shanghaiward with its cargo of fish from the ocean, wooden poles from Fukien, or rice or tea from the upper Yangtze. Now one meets a coast steamer moving down stream destined for Tientsin or Hongkong, a sidewheeler passenger steamer in a bright coat of canary yellow 
bound for Hankow and the intermediate Yangtze river ports. The nearer the steamer comes to Shanghai-and it will be an hour or two after entering the Whangpoo before the steamer will reach her dockthe greater will be the amount of shipping in the river (Fig. 2): British, Japanese, Italian, Norwegian, Dutch, French and American freighters. To an American who has visited Shanghai at intervals during the past

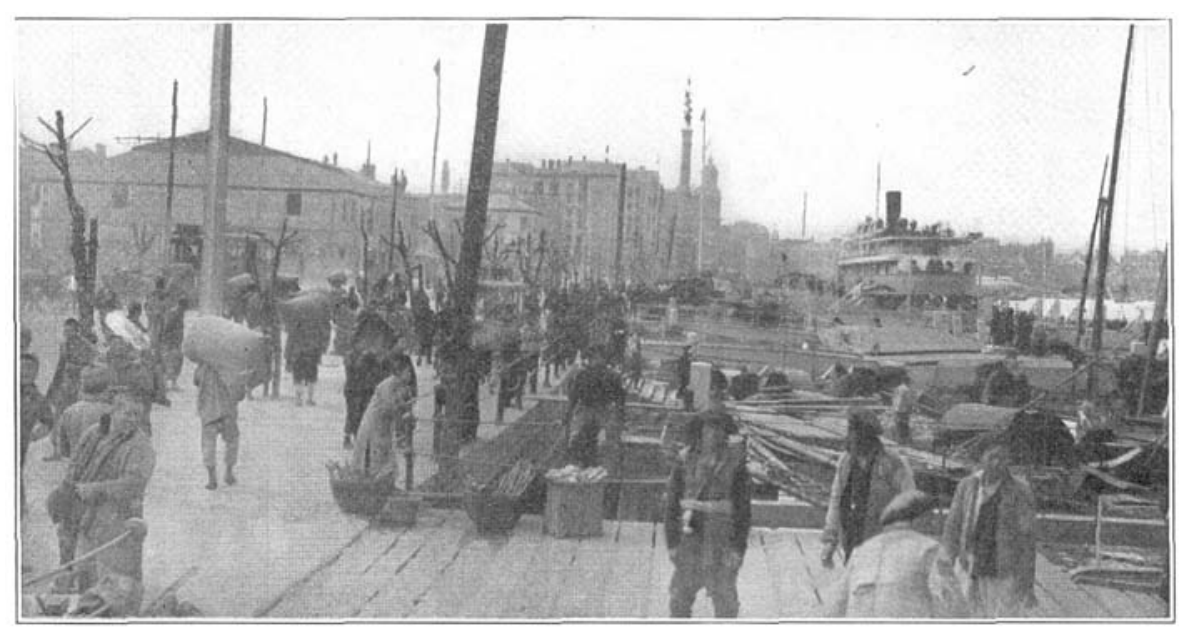

FIG. 5. Along docks at Shanghai

twelve years the recent increase in the number of ships flying the Stars and Stripes is strikingly significant. Another effect of the war on the shipping is the plainness with which, in a large number of instances, the vessel's name is printed on her side.

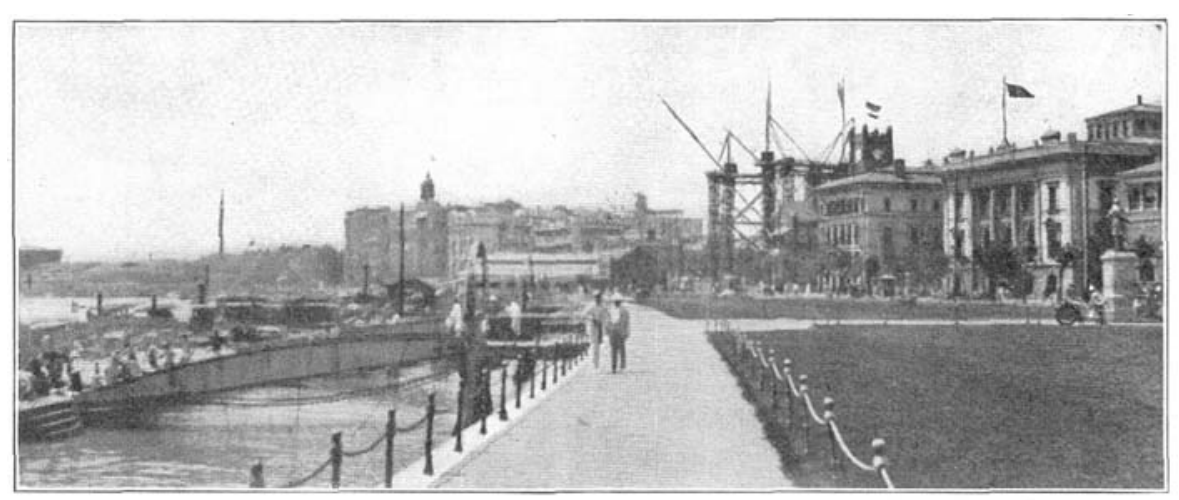

FIG. 6. Along the the "Bund" at Shanghai 
Before the steamer has corered quite half the distance from Woosung to Shanghai the experienced passenger will point out a group of buildings on the right bank as the Shanghai College, a growing institution, beautifully located on the river front with room to grow. Then the lower warehouses of the Asiatic Petroleum and Standard Oil Companies are passed, later the plant of the China Export \& Import Lumber Co., the Shanghai Waterworks, cotton spinning mills, warehouses in increasing numbers: and thru openings between, one catches hasty views of passing trolley cars and realizes that he is nearing the city. The rapidly increasing number of freight and passenger ships at the docks, war vessels at anchor in midstream, and numerous tugs and small craft playing at hide-and-seek between the larger ressels, all verify the realization that Shanghai is reached (Figs. $3,4,5$ ).

The steamer slips into her dock, and before he rushes to his cabin

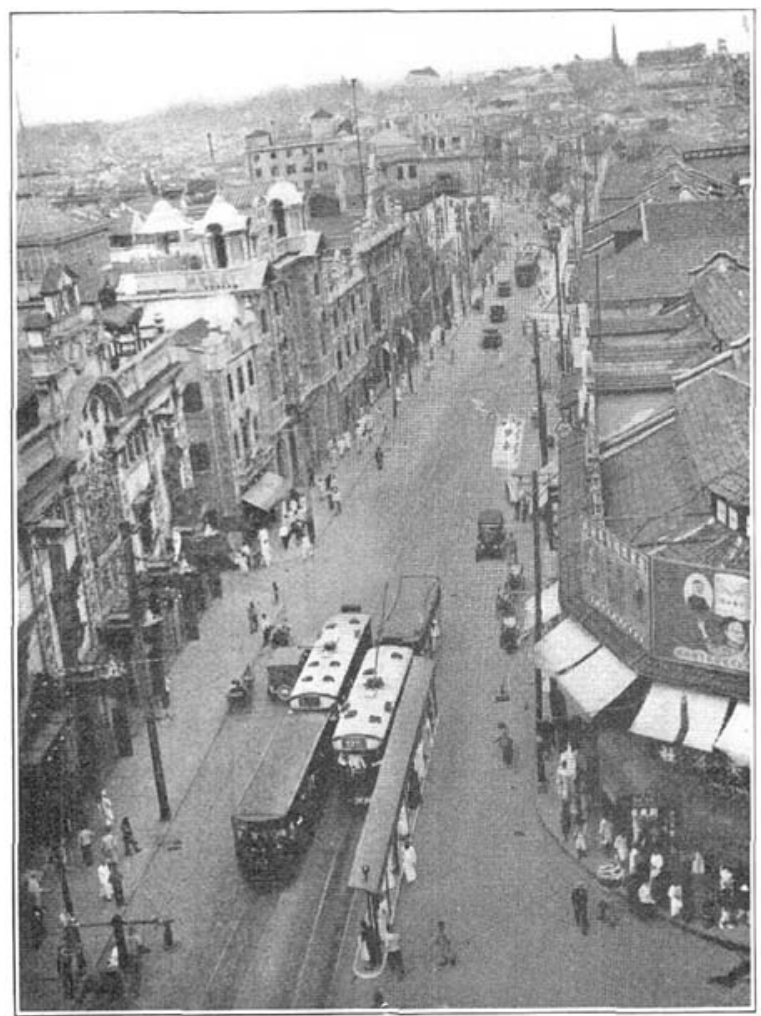

FIG. 7. Trolley cars, speeding automobiles and dashing "rickshas" on Nanking Road to collect the last of his personal effects, the passenger catches a glimpse of the river front a little farther up stream; the American flag among those of various consulates; a steel bridge carrying its heary traffic: the "Public Gardens" with their beautiful flowers and trees on the water front: the "Bund" (Fig. 6) which is the riverside street with its oriental style buildings of thirty or forty years ago, giving place today to six and eight story modern office buildings; the handsome customs building with its clock tower from which the time is chimed every quarter 
hour; the Zikawei Observatory signal tower which warns seamen of the weather conditions outside and gives them the time each noon; trolley cars, rushing horse carriages, speeding autos, dashing "rickshas," slow-moving wheel barrows, coolies with loads over their shoulders. Men and women of all races and costumes pass before the vision, a fascinating mixture of East and West (Fig. 7). The mob yelling on the dock alongside recalls the passenger from his contemplation of the scene and he realizes he has reached Shanghai.

\section{NATIONAL COUNCIL MEETING}

The next annual meeting of the National Council of Geography Teachers will be held the afternoon and evening of December 26 and the forenoon of December 27, 1922, at the University of Michigan. A program is now being prepared by President $R \mathrm{D}$ Calkins, details of which will be announced later. The Association of American Geographers will hold their annual meeting at the same place immediately following the National Council meeting. Make your plans now to attend these meetings! Come and get acquainted with your fellow workers!

\section{A CORRECTION}

To the Editor of the Journal of Geography:

In his very able review of my "Battlefields of the World War" published in your April issue, Dr. Kirk Bryan states that American military men will find in my book no reference to the work of the Geologic Staff of the American Expeditionary Force under Lieut. Colonel Alfred H. Brooks, and only a casual footnote reference to his report on "The Use of Geology on the Western Front." As some of your readers who have not the book before them might interpret this to imply a lack of respect on my part for the valuable work done by Colonel Brooks and his associates, I hope you will do me the courtesy to print this communication, including the appended quotations from the book: It is only fair to Dr. Bryan to add that the pages of "Special Acknowledgements," inserted just before the book was issued, were not included in a few preliminary copies privately distributed some weeks before publication was completed. It is evident that Dr. Bryan had in hand one of these preliminary copies. ${ }^{\mathrm{T}}$

Quotation from the section headed "Special Acknowledgments," in the Introduction:

"In describing the Battlefields of Verdun and Lorraine the author has omitted discussion of the excellent work of the geologists of the American Expeditionary Forces, in part because a special report on that work by the Chief Geologist himself was in preparation while the present text was being written. Lest this omission be construed as indicating failure to appreciate the high value of the work done by the Geologic Section of the American Expeditionary Forces, the author desires to emphasize in this special manner the achievements of a geological service which at the end of the war ranked first among the Allied Armies. It is a pleasure to acknowledge at the same time the author's indebtedness

1 The copy supplied by the publisher was marked "incomplete" and we were informed that it was "incomplete" only in respect to maps. EDrror. 